\title{
Influence of Managerial Accounting Skills on SME's on the Success and Growth of Small and Medium Enterprises in Kenya.
}

\author{
Marion Mbogo
}

\begin{abstract}
Several studies show that most small and medium businesses fail within their first three years. Although the role of factors such as access to funds and culture has been widely studied, the influence of owner/manager practices and capabilities have generally been ignored. To bridge this gap, this paper investigates the managerial business practices and capabilities used by SMEs such as strategic management, financial, marketing, human resource and ICT and their influence on decision making for enterprise success and growth.
\end{abstract}

Data was collected from Kenya Industrial, Research and Development Institute (KIRDI) incubated SMEs in Nairobi. A census research design was used, with a self administered questionnaire given to all participants.

The results show that owner/manager capabilities in financial, marketing, human resource and managerial accounting influence decision-making, and consequently SMEs success and development. The paper concludes that training level and managerial accounting capabilities of owner/manager have a strong, positive and significant influence on the decision making and consequently are critical for the success, growth and survival of SMEs.

Key words: Small and Medium Enterprises, owner/manager, managerial practices, managerial accounting, decision making

\section{Introduction}

Small and medium-sized enterprises (SMEs) in any country contribute to economic growth. In Kenya, the SMEs play an important role in employment and wealth creation, income distribution, accumulation of technological capabilities and spreading the available resources among a large number of efficient and dynamic small and medium size enterprises (IDRC, 1993). According to the Economic Survey (GOK, 2009) the SME sector contributed $79.8 \%$ of new jobs created in that year in Kenya.

Small and medium-sized enterprises (SMEs) are sometimes classified differently in various countries. The classification of the enterprises for this study is based on the Government of Kenya's 1989 Development Plan and the Sessional Paper No.2 of 2005 (GOK, 1989, 2005). According to the documents, firms are classified by the number of fulltime employees which they engage. Firms which employ less than five full-time workers are referred to as micro enterprises. Those employing between 5 and 49 workers are called small scale enterprises (SEs) and those with 50-99 full-time employees are medium enterprises 
(MEs) while those with 100 and above full time workers are referred to as large enterprises (LEs) (GOK, 1989, Sessional Paper 2, 2005).

According to the Kenya National Bureau of Statistics (GOK, 2007), three out of five businesses fail within their first three years of operation. One of the most significant causes of failure is the negative perception towards SMEs (Bowen, Morara, \& Muriithi, 2009) Amyx, 2005). Potential clients perceive the small business as lacking the ability to provide quality services and hence not trustworthy. Many of the problems faced by small businesses are inevitably centred on the owner/manager. There are two key factors that impact on the way most of these SMEs are managed. First, decision making is concentrated on one or two owner managers (Greenbank, 2000; Keasey and Watson, 1993). Second, owner/managers often work at both the management and operational levels and therefore acquire information about the market and the performance of their business through personal experience rather than relying on feedback mechanisms from other sources (Greenbank, 1999).

Despite the high rate of SMEs failures, their contribution to the economy growth cannot be ignored. In Kenya, the SMEs play an important role in employment and wealth creation, income distribution, accumulation of technological capabilities and spreading the available resources among a large number of efficient and dynamic small and medium size enterprises (IDRC, 1993). According to the Economic Survey (GOK, 2009), the SME sector contributed $79.8 \%$ of new jobs created in that year in Kenya. Consequently, the Kenya's development plans for the 1989-1993, 1994-1996 and 1997-2001 periods put special emphasis on the contribution of small and medium size enterprises in the creation of employment in the country (GOK, 1989, 1994, 1997). It is common knowledge that organizations, large and small alike, struggle to develop in an external operating environment which is characterized by turbulence and uncertainty. Among the challenges in the Kenyan Environment that limit SMEs growth includes the lack of access to credit, management skills, communication and infrastructure. Lack of managerial accounting skills for decision making and lack of technical skills are as much obstacles to developing a small business as is the inability to access credit. Studies have shown that small firms may lack types of knowledge necessary to innovate and compete successfully, hence there is need to investigate the business owner/managers' characteristics such as managerial accounting capabilities, education level, business skills and information communication technology (ICT) experience on the success and growth of small 
and medium enterprises in Kenya. For the small firm, any simple management error may spell its death (Wyer and Mason, 1999).

In order to successfully establish and grow these small and medium business entities, there are many crucial decisions that must be made. Many of these decisions relate to sourcing of capital and ensuring that such capital is utilized in a manner that results in the optimal growth and profitability of the entity. In order to achieve this objective, it is necessary for the entity to possess financial management and accounting skills (Collis and Jarvis, 2002). The owner/ manager can possess the skills or he can recruit employees having them. The fact that the failure rate of 1 in every 3 continue to occur is evidence that interventions to reduce this phenomenon are required. These interventions cannot be haphazard; they have to be informed by the existing practice and its effect on decisionmaking. This paper therefore is an effort to contribute towards this gap by identifying the major owner/manager characteristics that may cause possible business failure, and required interventions. Hence the purpose of this study was to examine the main characteristics of the business owner/managers' and their influence on the SME, the current provision for management development as it relates to the SME and the owner/manager's managerial practices for decision making in the running of the business to enhance growth.

In essence the paper has answered the following two research questions.

1. What is the influence of the owner/manager's managerial activities on the success and growth of SMEs? and

2. Do managerial accounting capabilities used by the owner/manager affect decisionmaking for the success and growth of the SME?

\section{THEORETICAL FRAMEWORK AND RESEARCH HYPOTHESIS}

Small and medium business research represents a vast field of study that incorporates many disciplines from the social sciences in addition to business and thus adds to the complexity of undertaking research in this area (Giroux, 2008; Curran and Blackburn 2001). These provide a summary of how research on small businesses has spanned beyond the realm of business to include anthropological, psychological, sociological, geographical and historical approaches. According to Kibera (2000, the SMEs are engaged in many business activities depending on the economic and political environment existing in that country. They are found in the agriculture, manufacturing, construction, transport, hospitality, educational and professional services sectors. 
These cross-disciplinary influences on small firm research have contributed to the fragmented nature of small business management theory (D’Amboise and Muldowney, 1988), which attempts to understand small business management processes.

According to Jennings and Beaver $(1995 ; 1997)$ managerial activity in small firms is categorized as an "adaptive" process that has little similarity to the classical approaches that define what managers do in more conventional terms. In their framework The Small Firm Management Process (Jennings and Beaver, 1997), the management functions and activities that must be fulfilled by owner-managers to ensure adequate small firm performance are identified and differentiated between core, managerial and strategic levels of management functions that are unique to each organization. This framework outlined in Figure 2 suits the understanding of small business management process since it takes into account the complex and unpredictable nature of managing a small business.

This study analyzes the distinctive management practices and skills that are integral to the SMEs management process. The analysis examines the owner/manager managerial capabilities which include strategic, financial, marketing, human resource management, ICT and managerial accounting practices that influence decision making for the success and growth of the SMEs. We contend that managerial capabilities have a critical impact on decision making and ultimately on firm success and growth. Accordingly, decision making is one of the critical drivers of the SME performance (O'Regan, Sims, \& Ghobadian, 2005).

ENTREPRENEURIAL SKILLS

(Adaptive and Organic)

Innovation

Risk taking

Tactical Planning

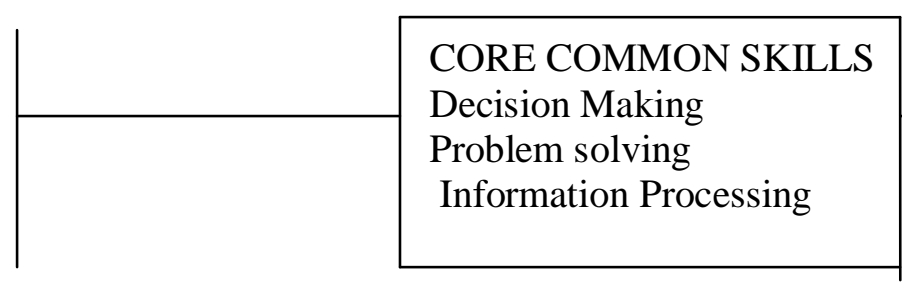

Negotiation

Trouble shooting

MANAGERIAL SKILLS

Inter-personal

STRATEGIC LEVEL

\section{OWNERSHIP SKILLS}

(Predictive and Mechanistic)

Strategic Planning Human Resource Planning Market Planning

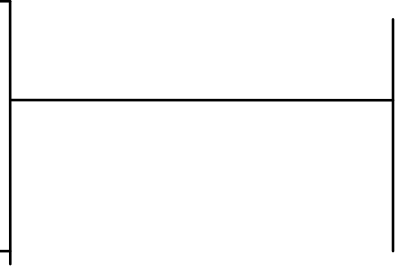

Organizing

Coordinating

Formal Communication 
Communications

This framework distinguishes between the different skills inherent in managing a small business. To gain a complete understanding of how the owner/manager operates the small business, a more detailed analysis of the management practices is required. According to Jennings and Beaver (1995) one of the primary ingredients in small business success must be the managerial competence of the owner/manager. (Giroux, 2008) posits that there is a tendency to categorize the management skills required to manage a small business into functional areas. Such categorization supports the intrinsic belief that small businesses increase their chances of success when managers are competent in core functional areas such as strategic planning, finance, marketing, operations and human resources management (Balderson, 2003; Giroux, 2008). However, due to their size, small businesses have limited resources which hinder a wide variety of individuals to fulfill specific functional roles. The owner/managers must therefore have the ability to fulfill various functional roles in order to ensure the effective management of their business on any given day (Giroux, 2008). Recent studies of survival rates for small business (Baldwin, Bian and Dupuy, 2000; Giroux, 2008) find that a lack of management skills is among those that contribute to failure and that many small firms fail as a result of a deficiency in their internal functioning rather than as a result of externally generated circumstances. This study therefore conceptualizes that when the owner/manager defines the firm objectives, he/she will provide the functional roles within his or her managerial capabilities to ensure firm performance for growth and success. Figure 2 presents the research framework examined in this study and integrates the theoretical perspectives of previous studies discussed above. 


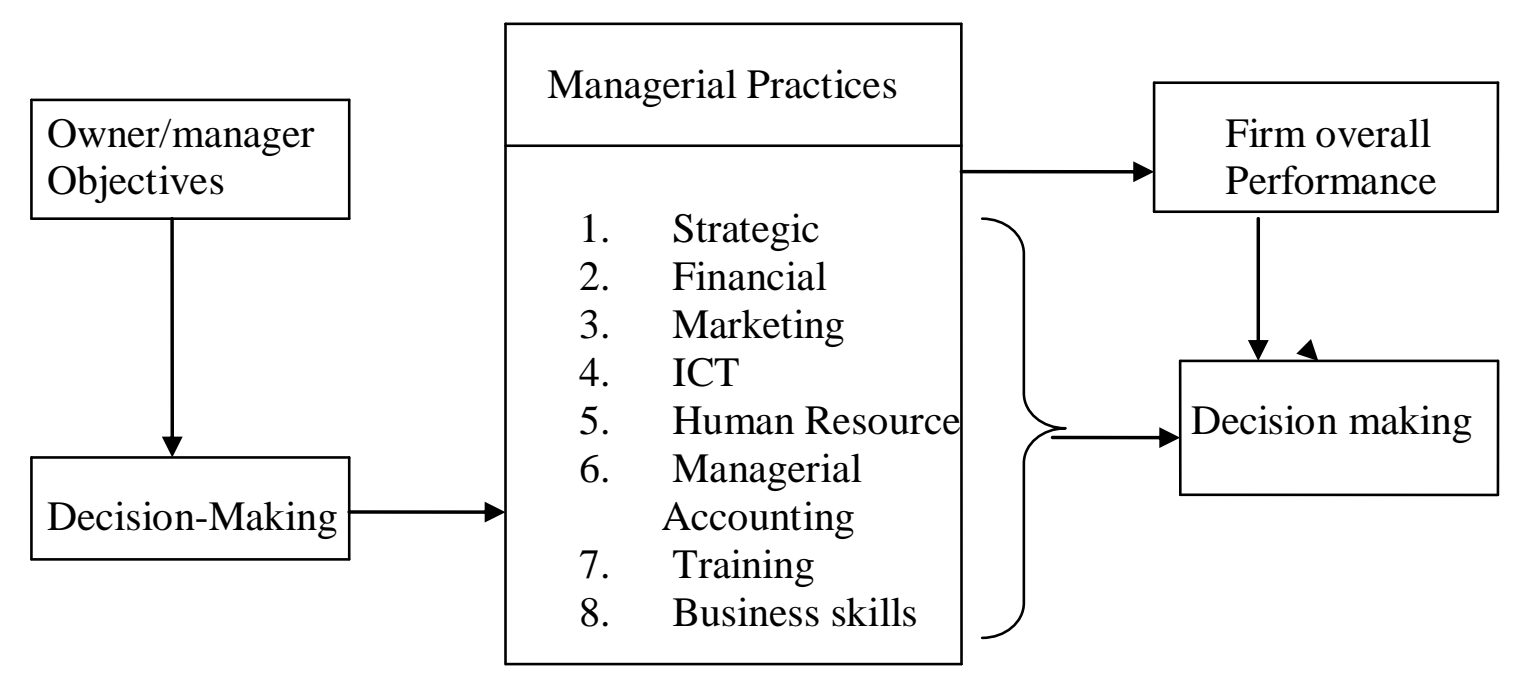

Figure 2.Research Framework adapted and modified from Cragg, P., and King M. (1988)

\section{Strategic management}

Once the goals of the firm have been defined they become the basis for planning and future development (Perez de Lema and Durendez, 2007). Management planning and monitoring are crucial factors in guaranteeing the correct development course of a business as well as generating profits. Having a well thought out strategy is an important activity for both SMEs and large firms (Ropper, 1997). Strategy is a key factor for the competitiveness and profitability of a company (Chandler, 1962; Ansoff, 1965). Success in strategy implementation depends on the internal factors, such as the way the owner/manager makes decisions in the current environment, the owner/manager himself or herself and the human resource capacity. The external factors include the economic cycle, competition, and demand fluctuations (Thomson and Strickland, 1993). In order to compete, companies deliberately choose the appropriate strategy for their specific environment and after sometime, successful firms develop an identifiable and systematic environmental adaptation system (Miles and Snow, 1978).

The relationship between formal strategic planning and performance has been examined by several authors. Some studies present a positive relationship between performance and strategic planning (Robinson, 1982; Bracker, Keats and Pearson, 1988; Hahn and Powers, 1999; Perez de Lema \& A., 2007). In contrast, other authors have concluded that a significant relationship does not exist (Kallman and Shapiro, 1978 ; Orpen, 1985; Shrader and Dalton, 1989). Previous research suggest that various variables were used 
to measure strategy. These include: planning formality (O'Regan and Ghobadian, 2004), external assistance in strategic planning (Robinson, 1982), the use of sophisticated planning techniques (Bracker, Pearson, and Keats, , 1988), new product introduction, ownership and control (Roper, 1997).

Strategy entails the deployment of resources to achieve organisational aims and objectives. This entails marshalling the firm's internal resources to meet the demands, challenges and the external operating environment in pursuit of its objectives ( $O$ 'Regan and Ghobadian, 2004). According to Pettigrew and Whipp (1991) strategy comprises of a" trinity of forces". The alignment of the internal and external operating environments is only one aspect of strategy that is termed as strategic context. The other two forces are the "content" and "process". Content relates to the distinct elements of the strategic plan and is firm specific. Process relates to the nature of the actions deployed in the development of the contentof the strategic plan. It involves a succession of interelated steps each of which entails the consideration of a series of factors and the deployment of the relevant analytical tools (O'Regan and Ghobadian, 2004).

Clearly, the factors considered during the process can potentially reduce the risks involved and facilitate the more effective deployment of the strategy content. This is an important consideration for the SMEs as they are faced with a lot of risks and having proper strategies will greatly reduce the risks involved. A small margin of error can have devastating effects on the SME's growth unlike large businesses. Literature points out that while most firms emphasise strategic planning, the position in relation to SMEs is blurred and unclear (O'Regan and Ghobadian, 2004). For these reasons, this study postulates that strategic management capabilities of the owner/manager positively influences firm performance and hence the growth of the SME. It is thefore necessary to investigate the role of strategic management on the development of the SME in a developing country. In the light of the literature considered, the preceding discussion suggests the following hypothesis:

H1. Owner/manager strategic management capability in the SME positively influences decision making for the success and growth of the firm. 


\section{Financial management}

De fries (1989) argues that a major theme in the life and personality of many entrepreneurs is the preoccupation with control which inevitably affect their power relationships and consequently the interpersonal action. He goes on to say that the entrepreneur has a great inner struggle with issues of authority and control and has difficulty working with others. The issue of control of the SME owner/manager making all the financial management decisions has important implications for the firm's functioning and may lead to low staff morale and customer service which in turn may contribute to the failure or success of the SME.

Perren et al. (1999) posits that owner-managers in small firms move from informal methods of financial management and decision-making to more formal methods depending on the development of the businesses. Furthermore, financial management decisions are based on evolutionary change and dynamic processes, which rely on relationships established between owners and external advisors whether accountants, bank managers or other professionals (Deakins, Morrison and Galloway, 2002). Small businesses are less transparent when providing financial information and are more reluctant to facilitate voluntary accounting and financial information. Financial controls may be used with the main purpose of tax minimization instead of for strategic and performance decisions (Perez de Lema and Durendez., 2007; Trostel and Nichols, 1982). The majority of small firms prepare regular income and expenditure reports but use other financial reports less regularly. Small businesses often falter due to business-related problems such as poor financial management (Holland and Boulton, 1984). McChlery and Godfrey (2005)found that "the principal catalysts to sound financial management systems within the small firms sector appeared to be: computerised accounting systems, highly motivated owners/directors of the firm, qualified internal accounting staff, proactive external accountants and pressure from providers of finance. From these discussions, this paper has postulated that owner/manager financial management capabilities will positively influence growth of the firm and consequently success of the SME. It is therefore rational to investigate the role of this characteristic in the SME development, particularly in a developing country, where human development is persistently a challenge. The following hypothesis is formulated: 
H2. Owner/ manager managerial capability in financial management positively influences decision-making for the success and growth of the firm,

\section{Marketing management}

Previous research shows that SMEs have unique characteristic that differentiate them from conventional marketing in large organizations (Carson, 1990). These characteristics may be determined by the inherent characteristics and behavior of the owner/manager or by the size and stage of development of the business. Such limitations are finance, time, marketing knowledge, lack of specialist expertise and limited impact in the marketplace. Most owner/managers make most decisions on their own, respond to current opportunities and circumstances and so end up with decisions made in a haphazard and chaotic manner according to personal and business priorities at any point in time (Scace and Gofee, 1980). SMEs do not conform to the conventional marketing characteristics of marketing text book theories but are characterized by the limitations outlined above. Thus, their marketing is likely to be haphazard, informal, loose, unstructured, spontaneous, reactive, built on and conforming to industry norms. (Gilmore, 2001). To understand how the marketing activity of the owner manager influences the decision making and consequently the firm performance, it is necessary to carry out a research. This study investigates how the marketing management affects decision making within the SME and the hypothesis is therefore formulated:

H3. The owner/manager managerial capability in marketing management positively influences decision-making for the success and growth of the firm.

\section{ICT Management}

According to Marriott and Marriott (1999) owner/managers with good financial skills make more use of computers to produce financial information. Those with limited financial skills place little value on the financial statements produced by their external accountants. Also, small businesses use computers in their business for the preparation of accounts, but usually not to their full potential. Frequently, the computerized accounting packages were used to prepare profit figures, which were erroneous and incomplete.

Nayak and Greenfield (1996) found that the computer users of small businesses were more likely to have complete records of cash book, debtors, creditors and nominal ledgers than enterprises with hand written records. Small business computer users are also more 
likely to have a greater knowledge of debtor and creditor payment periods. Furthermore, the more successful the small enterprise, the more likely it is to have more formalized and extensive business records. Small enterprises do that in order to obtain more regular accounting information to help future decision making as the owner/managers experience how their decisions impact on profits. This study investigates the extent of use of ICT in the SMEs by the owner/managers and their employees and the impact of ICT management on the decision making for the success and growth of the SME and formulates the following hypothesis:

H4. The owner/manager managerial capability in ICT positively influences decision-making for the success and growth of the firm.

\section{Human resources management}

Insufficient attention is paid to human resources and very often employees occupy different positions at the same time. In almost all the SMEs investigated, there is no one person responsible for human resources management, with the exception, in some cases, of the presence of an external consultant. Often employees are mainly managed unsystematically by the entrepreneurs, and individual performances and knowledge are rarely measured using ad hoc systems. The main criteria used are informal and based on trust and feelings. There have been some sporadic attempts to link rewards to productivity or other generic objectives; however, the lack of formal performance management is an impediment to the use of reward systems and to empowerment processes. Managerial skills are often lacking and therefore managerial tools and techniques are perceived as being of little benefit to the company. Most SMEs in developing economies lack strategic orientation and longterm vision. They put greater emphasis on short-term profits rather than building long-term competitive potential.

Recruiting new employees is one of the biggest challenges racing small firms, and a key component of organizational success. Previous research on the staffing practices of small firms has found that small firms tend to rely on social networks to attract workers, particularly at the inception of the firm. However, as SMEs grow in size they exhaust the supply of suitable family and friends, forcing them to recruit strangers to fill work positions. Since the performance of SMEs is closely related with their ability to recruit strangers the 
development of effective recruitment policies and practices in small firms has significant implications for organizational survival.

Curran (1988) posits that small businesses inability to offer career paths or reward packages equitable with large organizations can marginalize the small firm in relation to the labour market and the attraction of quality workforce. It is for these reasons that this study postulates that human resources management has a positive influence on the decision making and consequently on the growth and development of the firm and hence the need to investigate.

H5. The owner/manager managerial capability in human resource management positively influences decision-making for the success and growth of the firm.

\section{Managerial accounting skills}

Accounting research shows that management accounting is a facilitator of control in firms as it can keep the distance between the head office and the subsidiaries or branches manageable (Moilanen, 2008; Quattrone and Hopper, 2005; Kirk and Mouritsen, 1996). Management Control systems embraces a variety of activities undertaken by middle management. These include planning, coordinating, communicating, evaluating, acting and influencing (Antony, Dearden, and Govindarajan, 1992). The literature on management control systems describes formal changes in management accounting and control systems as being essential to organizational change across life-cycle stages (Moores and Yuen, 2001; Davila and Foster, 2005).

According to Vaughan and Tague-Sutcliffe (1997), many small enterprises failed in China due to lack of information. Lybaert (1998) found a positive relationship between the extent of information usage and the performance of small enterprises. The three-part division of management accounting suggested by Simon et al. (1954) is appropriate for the exploration of managerial accounting information in small businesses namely score keeping, attention directing and problem solving. Randall and Horsman (1998) suggested that score keeping in small businesses was performed as a result of the data processing and reporting in the financial accounting function of the business. In contrast to score keeping information, Randall and Horsman (1998) argued that attention directing and problem solving categories 
of information were most likely to be absent in small businesses.

The possible types of managerial accounting information relevant to small businesses such as break-even point, analysis of costs, non-financial indicators, key financial ratios and performance by product, were outlined in the International Federation of Accountants Chartered Institute of Management Accounting - IFAC and CIMA (1998) Financial Management Fundamentals package. This package of advice also discussed a number of methods such as benchmarking, debt factoring, invoice discounting and total quality management for small enterprise management to consider. Furthermore, the package provided a graphical illustration for each of 21 information topics such as funding structure, profits and loss account - actual versus budget, working capital, cash flow projection, breakeven calculation, contribution by products, market share and inventory for small enterprise management to monitor the changes and trends appearing.

A study by Hall and Young (1996) showed that management accounting was an important deficiency in 38 per cent of 241 failed small enterprises surveyed. Similarly, Randall and Horsman (1998) found that the lack of management accounting information contributed to small enterprise failure. They also found that there were barriers preventing external accountants from providing managerial accounting information for owner/manager's decisions. A number of studies have suggested that the quality of managerial accounting information used within small enterprises had a positive relationship with their performance (Raymond and Magnenat-Thalman, 1982; Holmes and Nicholls, 1989). Managerial accounting information in small businesses is therefore an important topic for research.

Randall and Horsman (1998) argued that the owner/managers were vague about some of the techniques of management accounting, which might be useful in their business. They also argued that the attitudes of the owner/managers and the range of services offered by actual and potential information providers limited the level and role of managerial accounting information available to the owner/managers. Randall and Horsman (1998) stressed that even expert owner/managers in management were personally unlikely to understand the power of some techniques, which might be good indicators of a high level of risk of failure for businesses.

This study postulates that managerial accounting capabilities will positively influence decision making and hence growth of the SME. It is therefore rational to investigate the role of management accounting skills in the development of the SME in a developing country. 
H6. The owner/manager managerial capability in managerial accounting positively influences decision-making for the success and growth of the firm.

\section{Training}

According to (Taylor and Thorpe, 2004), training is often viewed as the vehicle for fostering learning in businesses. There has been considerable research into the nature and extent of training in small firms, and the literature suggests that, in general, formal training approaches do not appeal to the small business sector in many countries such as Australia (Field, 1998), England (Sadler-Smith et al., 1998), New Zealand (Massey, 2004), Scotland (Kerr and McDougall, 1999) and the USA (Fernald et al., 1999). A research by Sadler-Smith et al. (1998) found that small firms were significantly less likely to have training budgets than larger firms, the identification of training needs was practiced more frequently in the larger firms, and the amount of formal training and development activity was positively related to size. Similarly, based on a comprehensive review of the literature on employer-based education and training Long et al. (2000, p. 43) conclude: "there is overwhelming evidence that larger firms and workplaces provide more training than smaller firms and workplaces, and that these differences are large". Thus, it seems well established in research literature that formal training is generally not suited to small firms for a variety of reasons, including cost, time, and perceived lack of relevancy (Abbott, 1995; (Gibb, 1998)Gibb, 1998);

Interest in employee learning in small firms has focused on the provision or absence of "training" as the measure of "learning" (Field, 1998; Walton, 1999).

Recent thinking on training in small firms suggests that informal, in-house training fits well with the constraints under which small firms operate, and may be effective in improving firm performance (Curran, 2000; Field, 1998; Rowden, 1995; Walton, 1999). Hence, the traditional view that only formal training is "real" training is increasingly being questioned. These commentators argue that training models derived from large firm learning experiences and practice may be fundamentally inappropriate for small firms. And facilitators research, theorizing, and practice recommendations regarding employee learning, may be more fruitful if based on different assumptions. There appears to be a growing body of work that adopts a perspective that is broader than formal training in examining learning processes in small firms.

Education is one of the factors that impact positively on growth of firms (King 
and McGrath, 2002). Those entrepreneurs with larger stocks of human capital, in terms of education and (or) vocational training, are better placed to adapt their enterprises to constantly changing business environments (King and McGrath, 1998). Infrastructure as it relates to provision of access roads, adequate power, water, sewerage and telecommunication has been a major constraint in the development of SMEs (Bokea, Dondo and Mutiso, 1999).

In small businesses, owner managers may not have the necessary skills, abilities, time and aspiration levels to adapt to more formalized approaches hence it is necessary to get the relevant training. For this reason, this study investigates the role of training in the SME and its impact on decision-making in the firm. The following hypothesis is formulated:

H7. Training in the managerial skills positively influences decision-making for the success and growth of the firm.

\section{Business Skills}

Business activities of enterprises have a direct relationship with their needs for business skills. The issue of what constitutes effective small business management practice and how they impact the performance and potential success of small firms is a significant one in the field of small business management research and has been the focus of many studies (Stokes and Blackburn, 2002; Sadler-Smith et al,2003). These studies have a behavioral emphasis and have identified core competencies and skills that are essential to the effective management of a small business in order to ensure its survival and growth. These include, vision, people, operations, resources, customer service, financial skills, planning, strategy, marketing and many others (Gasse, 1997, Gadenne, 1998, Zinger, leBrausseur and Zannibi, 2001). This study examines the extent to which the owner/manager competency in business skills influences decision making in the firm performance and subsequent success and growth and formulates the following hypothesis:

H8. Business skills positively influences decision-making for the success and growth of the firm.

\section{Decision making}

Tait (1990) argues that: it is the owners/managers' decision-making perceptions which 
govern their behavior through the various stages of the decision-making process. For instance, the perception of need by owners/managers is a critical factor in the decision by owners/managers to participate in management education programs. It is clear that small business owners/managers vary considerably in their perceptions of a need for formal management education. Previous research has found that management decision-making and organizational structure revolves around the preferences and interests of owner-managers who take all the major decisions and monitor all activities. (Pansiri et al, 2006; Hitt et al 1996). While such approaches and structures enable strong control over the firm, organizational success or failure in SMEs is seriously affected by the managerial competencies of the owner-managers. This study investigates the extent to which the owner/manager managerial capabilities influence the decision-making for the growth and success of the firm.

\section{RESEARCH METHODOLOGY}

\section{Data collection and analysis}

Data was collected from Kenya Industrial, Research and Development Institute (KIRDI) incubated SMEs in Nairobi. A census research design was used, with a self administered questionnaire given to all 31 participants. The questionnaire included the construct items adapted from previous studies (Baldwin, Bian, and Dupuy, 2000; Giroux, 2008) and some questions on demographics. The respondents were required to complete the questionnaire voluntarily and the researchers provided assistance in filling up the questionnaires where required All the questionnaires were returned and were checked for plausibility, integrity and completeness resulting in all cases being usable.

All the items used to measure the constructs were adapted from previous research but modified to fit the specific context of this study. Eight independent variables with various items and one dependent variable were identified and measured using a five-point scale with polar anchors ranging from 1 (strongly disagree) to 5 (strongly agree). The independent variables were strategic management, financial management, marketing management, ICT, Human resource management, managerial accounting skills, training and business skills. The dependent variable was decision-making.

The respondents were business owners or those involved in the start-up and day to day running of these businesses. The data gathered was analyzed and processed using Statistical Package for Social Sciences (SPSS) for windows and presented using descriptive statistics. 


\section{RESULTS AND DISCUSSION}

Thirty one responses were completed by all the currently incubated SME's business operators representing a response rate of one hundred percent. All the cases were usable for further analyses. There were more male than female respondents $(67.7 \%, 32.3 \%)$. Over $85 \%$ of the sample respondents are between eighteen and thirty five years old. Sixty seven point seven percent fall in the age group of between 20 and 40 years while $33.2 \%$ are above 41 years. Forty five point two percent are sole proprietors while the $22.6 \%$ are partnerships and the rest are registered companies and joint ventures. Thirty five point five percent of the respondents hold a diploma in their respective fields while $22.6 \%$ hold a masters degree and 19.4 per cent are qualified professionals in their line of duty. Table 1 summarizes the demographic profile of the respondents.

Table 1 Demographic Characteristics of the Sample $(\mathbf{N}=31)$

\begin{tabular}{|c|c|c|}
\hline Item & $\mathrm{N}$ & $\%$ \\
\hline Gender & & \\
\hline Male & 21 & 67.7 \\
\hline Female & 10 & 32.3 \\
\hline Age Group & & \\
\hline $20-30$ years & 12 & 38.7 \\
\hline $31-40$ & 9 & 29 \\
\hline $41-50$ & 5 & 16.1 \\
\hline Over 50 & 5 & 16.1 \\
\hline Type of Business & & \\
\hline Sole Proprietorship & 14 & 45.2 \\
\hline Partnership & 7 & 22.6 \\
\hline Joint venture & 1 & 3.2 \\
\hline Registered Company & 8 & 25.8 \\
\hline Other & 1 & 3.2 \\
\hline Highest Level of education & & \\
\hline Certificate & 3 & 9.7 \\
\hline Diploma & 11 & 35.5 \\
\hline Degree & 4 & 12.9 \\
\hline Masters & 7 & 22.6 \\
\hline Professional & 6 & 19.4 \\
\hline
\end{tabular}

Cronbach's alpha shown in Table 2 was used to assess the internal consistency reliability for each of the nine variables. All the constructs in the survey

questionnaire were analyzed to validate their reliability. Higher scores indicate more reliability for the measurements. All the constructs had acceptable scores. Since these constructs are proposed for the current study, further analysis in future research could be addressed. 
Table 2: Measurements Reliability Statistics for Each Construct

\begin{tabular}{|l|c|c|}
\hline Construct & Number of Items & Cronbach's Alpha $\alpha$ \\
\hline Strategic management(MGTSTRAT) & 5 & .851 \\
\hline Financial management (FINMGT) & 5 & .830 \\
\hline Marketing management (MKTMGT) & 4 & .833 \\
\hline Human Resource management (HRMGT) & 4 & .818 \\
\hline Managerial Accounting (MASKILLS) & 7 & .817 \\
\hline Training (TRAINING) & 3 & .828 \\
\hline Decision-making (DECMAKING) & 6 & .888 \\
\hline Business skills(BUSSKILLS) & 7 & .836 \\
\hline ICT skills(ICTSKILLS) & 4 & .822 \\
\hline
\end{tabular}

We conducted the Pearson correlations to have a high level of variables that have a significant influence on decision making. From Table 3 it is observed that managerial accounting skills and training level of owner manager have a positive and significance correlation with decision making of owner/manager. 
Table 3: Pearson's Correlation

\begin{tabular}{|c|c|c|c|c|c|c|c|c|c|}
\hline & 1 & 2 & 3 & 4 & 5 & 6 & 7 & 8 & 9 \\
\hline 1. $\begin{array}{l}\text { Strategic } \\
\text { management }\end{array}$ & 1 & & & & & & & & \\
\hline 2. $\begin{array}{l}\text { Financial } \\
\text { management }\end{array}$ & $.396(*)$ & 1 & & & & & & & \\
\hline $\begin{array}{l}\text { 3. } \begin{array}{l}\text { Marketing } \\
\text { management }\end{array} \\
\text {. }\end{array}$ & 0.317 & $.839(* *)$ & 1 & & & & & & \\
\hline $\begin{array}{ll}\text { 4. } & \text { Human } \\
\text { Resource } \\
\text { management }\end{array}$ & 0.229 & $.709\left(^{* *}\right)$ & $.750\left(^{* *}\right)$ & 1 & & & & & \\
\hline $\begin{array}{l}\text { 5. Managerial } \\
\text { Accounting }\end{array}$ & $.479(*)$ & $.465\left(^{*}\right)$ & $.437\left(^{*}\right)$ & $.386\left(^{*}\right)$ & 1 & & & & \\
\hline 6. Training & $.449(*)$ & 0.27 & $.366\left(^{*}\right)$ & 0.271 & $.546(* *)$ & 1 & & & \\
\hline $\begin{array}{l}\text { 7. Decision- } \\
\text { making }\end{array}$ & 0.353 & 0.261 & 0.37 & 0.173 & $.621(* *)$ & $.662(* *)$ & 1 & & \\
\hline $\begin{array}{ll}\text { 8. } & \begin{array}{l}\text { Business } \\
\text { skills }\end{array}\end{array}$ & -0.121 & -0.1 & -0.154 & -0.177 & -0.112 & -0.096 & -0.232 & 1 & \\
\hline 9. ICT skills & 0.295 & 0.354 & 0.168 & 0.29 & 0.235 & $.547(* *)$ & 0.194 & 0.048 & 1 \\
\hline
\end{tabular}

* Correlation is significant at the 0.05 level (2-tailed).

** Correlation is significant at the 0.01 level (2-tailed).

To confirm these relationships, we used applied Structural Equation Modeling (SEM) techniques using Amos 7.0. The structural model results are shown in Figure 1 and Table 2.

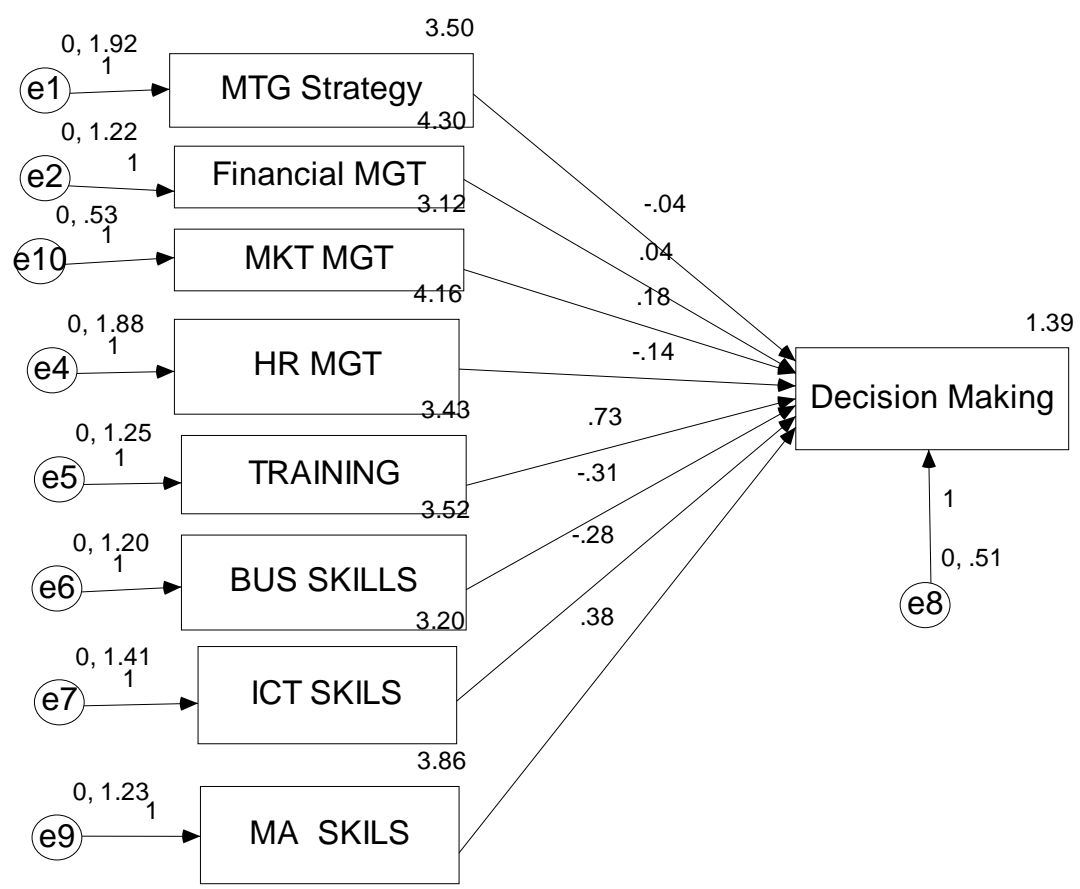

Chi-Square $=120.099($ Degrees of Freedom $=28)$ CMIN/DF= 4.289

Probability $=.000, \mathrm{RMSEA}=.331, \mathrm{TLI}=-.421, \mathrm{CFI}=.116$,

$\mathrm{NFI}=.195$ 
Figure 3: Structural Model Results.

From Figure 3 we see that the fit indices $C M I N / D F=2.957$ which is between the acceptable values (0 -3.0). Table 2 shows the Scalar Estimates (Group number 1 - Default model) using Maximum Likelihood Estimates.

Table 4: Regression Weights: (Group number 1 - Default model)

\begin{tabular}{|ll|rrrrr|}
\hline & Estimate & S.E. & C.R. & P & Label \\
\hline Decision-Making <--- & Strategic Management & -.039 & .107 & -.365 & .715 & par_1 \\
Decision-Making <--- & Marketing Management & .181 & .193 & .940 & .347 & par_2 \\
Decision-Making <--- & Human Res Management & -.137 & .102 & -1.344 & .179 & par_3 \\
Decision-Making <--- & Training & .727 & .125 & 5.805 & $* * *$ & par_4 \\
Decision-Making <--- & Business Skills & -.306 & .127 & -2.404 & .016 & par_5 \\
Decision-Making <--- & ICT Skills & -.279 & .118 & -2.370 & .018 & par_6 \\
Decision-Making <--- & Managerial Accounting & .382 & .126 & 3.024 & .002 & par_7 \\
Decision-Making <--- & Financial management & .043 & .129 & .333 & .739 & par_8 \\
\hline
\end{tabular}

$* * \mathrm{p}<0.001$

From Table 4, managerial accounting skills have a strong and positive influence on manager /owner decision making $(\beta=0.382, \mathrm{p}<0.05)$. This is an important finding with great practical implications. Similarly the results shown in Table 4, shows that training has a strong and positive influence on manager /owner decision making $(\beta=0.727, \mathrm{p}<0.001)$. This is an important finding with great practical implications that imply SMEs with trained owner manager/ have a higher chance of success. From the results of Figure 3 and Table 4, Table 5 shows the summary of Hypothesis Testing results. 
Table 5 Summary of Hypothesis Testing results

\begin{tabular}{|l|l|}
\hline Research Hypothesis & Supported \\
\hline $\begin{array}{l}\text { H1. Owner/ manager strategic management capability in the SME } \\
\text { positively influences decision making for the success and growth } \\
\text { of the firm. }\end{array}$ & No \\
\hline $\begin{array}{l}\text { H2. Owner/ manager managerial capability in financial } \\
\text { management positively influences decision-making for the success } \\
\text { and growth of the firm, }\end{array}$ & No \\
\hline $\begin{array}{l}\text { H3. The owner/manager managerial capability in marketing } \\
\text { positively influences decision-making for the success and growth of } \\
\text { the firm. }\end{array}$ & No \\
\hline $\begin{array}{l}\text { H4. The owner/manager managerial capability in ICT positively } \\
\text { influences decision-making for the success and growth of the firm. }\end{array}$ & No \\
\hline $\begin{array}{l}\text { H5. The owner/manager managerial capability in human resource } \\
\text { management positively influences decision-making for the success } \\
\text { and growth of the firm. }\end{array}$ & No \\
\hline $\begin{array}{l}\text { H6. The owner/manager managerial capability in managerial } \\
\text { accounting positively influences decision-making for the success } \\
\text { and growth of the firm. }\end{array}$ & Yes \\
\hline $\begin{array}{l}\text { H7. The owner/manager training level positively influences } \\
\text { decision-making for the success and growth of the firm. }\end{array}$ & Yes \\
\hline $\begin{array}{l}\text { H8. Business skills positively influence decision-making for the } \\
\text { success and growth of the firm. }\end{array}$ & No \\
\hline
\end{tabular}

\section{CONCLUSION}

This study sought to investigate the managerial business practices and capabilities used by SMEs and their influence on the decision-making for enterprise success and growth. The study has established that the training level and the managerial accounting capabilities have a strong, positive and significant influence on the decision making of owner/manager and consequently the success and growth of an SME.

The respondents clearly recognize the importance of managerial accounting capability as critical to decision-making for success and growth of the firm. This supports the conclusion by Marriott and Marriott (1999) that owner /managers with good financial and managerial skills made more use of computers to reduce financial and accounting information. As the SMEs grow they would increase their use of ICT to enhance the financial reporting. Further, the finding supports the conclusion of Nayak and Greenfield 
(1995) that the more formalized and extensive the business records are in the small business, the more regularly the accounting information is produced to help in future decision making.

The training level of the owner manager is critical to decision-making. This supports the conclusion of Perren et al (1999) that owner managers employed informal methods of information acquisition and control in running their businesses. Training would enhance the formal methods.

The study has also established that there is a significant negative correlation between business skills and decision making and a significant negative correlation between ICT skills and decision making. This would perhaps be as a result of the small sample and further research should be carried out using a larger sample to establish the course for the negative correlation.

\section{SUGGESTIONS FOR FUTURE RESEARCH}

This study was based on SMEs that were under incubation and may therefore not provide generalizations for the wider sector in Kenya. Additional research covering wider sectors should be done in future. Such research could also go beyond the indulgence of managerial capabilities on decision making and include the development of these managerial capabilities in small firms from a more general perspective within the context of the Kenyan environment. This investigation would then provide the SMEs with support that would appropriately reflect their reality and needs.

\section{References}

Amyx, C. (2005). The Perception Problem: Size Doesn't Matter. Washington Business Journal .

Ansoff, H. (1965). An analytical Approach to Business Policy for Growth and Expansion. New York: McGraw-Hill.

Antony, R. N., Dearden, J., \& Govindarajan, V. (1992). Management controlsystems.

Balderson, D. (2003). Canadian entrepreneurship and small business management (Vol. 5th Edition). McGraw-Hill Ryerson.

Baldwin, J., Bian, L., \& Dupuy, R. a. (2000). innovation strategies and performance in small firms. Cheltenham: Edward Edgar Publishing.

Beaver, G. J. (1995). Picking winners: the artof identifying successful small firms. In D. Hussey (Ed.), Rethinking Strategic Management. London: John Wiley and Sons.

Beaver, G., \& Jennings, P. (2005). Competitive advantage and entrepreneurial power: The dark side of entrepreneurship. Journal of Small Business and Enterprise Development, Volume:12/1, Pp.9-23. 
Bowen, M., Morara, M., \& Muriithi, S. (2009). Management of Business Challenges Among Small and Micro Enterprises in Nairobi, Kenya. KCA Journal of Business Management, 2 (1).

Bracker, J. S., \& Pearson, B. W. (1988). Planning and financial performance among small firms in a growth industry. Strategic Management Journal , 9, 591-603.

Carson, D. (1990). Some exploratory models for assessing small firm's marketing performance. European Journal of Marketing , 24, 11.

Chandler, A. D. (1962). Strategy and Structure. Boston: Institute of Technology Press.

Collis, J., \& Jarvis, R. (2002). Financial Information and Management of Small Private Companies. Journal of Small Buainess and Enterprise Development , 9 (2), 100110.

Curan, J. (1988). Training and Research strategies for small firms. Journal of General Management, 3.

D'Amboise, G. a. (1988). Management Theory for small business: attempts and requiem. The Academy of Management Review , 13 (2), 226-240.

Davilla, T. a. (21-23 September). 2005. Conference proceedings of the 3th International Conference on Perormance Measurement and Management. Nice.

Deakins, D., Morrison, A., \& Galloway, L. (2002). Evolution, financial management and learning in the small firm. Journal of Small Buainess and Enterprise Development, 9 (1), 7-16.

Gibb, A. (1998). Academic Research and the growth of ignorance = SME policy: mythical concepts, myths, assumptions, rituls and confusios. 21st ISBA National Conference. Durham University.

Gilmore, a. (2001). SME marketing in practice. Marketing Intelligence and Planning , 19 (1), 6-11.

Gilmore, A., Carson, D., \& O'Donnell, A. (2004 ). Small business owner-managers and their attitude to risk. Marketing Intelligence \& Planning, Volume:22 Issue:3 , Pg. 349360.

Giroux, I. (2008). An exploration of Owner-Manager problem solving practices in small firms: The central Vancouverisland experience. University of Hertfordshire.

GOK, G. o. (2009). Economic Survey. Nairobi: Government Printer.

GOK, G. o. (2007). Kenya Bureau of Statistics. Nairobi: Government Printer.

GOK, G. o. (1989-1994). National Development Plan. Nairobi: Government printer.

GOK, G. o. (2005). Sessional Paper No.2. Nairobi: Government printer.

Greenbank, P. (2000). Training micro-business owner-managers: a challenge to current approaches. Journal of European Industrial Training , 403-411.

Hahn, W. a. (1999). The impact of strategic planning sophistication and implementations on the frim performance. Journal of Business and Economic Studies , 5 (2), 19-36.

Hitt, M. A., \& Ireland, R. D. (1996). Strategic Management: Competitiveness and Globalisation. Minneapolis: West Publishing Company.

Holland, W. R. (1984). Buyouts, information asymmetry ad the family management dyad. Journal of Business Venturing , 19, 509-534.

IDRC, I. D. (1993). Small Enterprises Development and International. Ottawa, Ontario: IDRC.

Jennings, P. a. (1997). The performance and competitive advantage of small firms: a management perspective. International Small Business Journal , 15 (2), 63-75.

Jennings, P. B. (1995). The managerial dimension of small business failure. Journal of strategic change, 185-200. 
Kallman, E. A. (1978). "The motor freight industry: a case against planning", Long Range Planning.

Keasey, K. a. (1993). Small firm management- Ownership, Finance and Performance.

Kibera, L. W. (2000). The role of small Scale enterprisesd in socio-economic development and poverty alleviation in Kenya:a gender perspective. 7th Annual International Management Conference (pp. 38-48). Kampala: Makerere Business Journal Publications School.

Kirk, K., \& Mouritsen, J. (1996). Spaces of accountability. Systems of accountability in a multinational firm. Accountability: Power, Ethos and the Technologies of Managing , 94-107.

Lybaert, N. (1998). The Information Use: Its importance and some elements of influence. small business economics , 171-191.

Marriot, N. a. (1999). The provision of Fianancial Information to Smaller Companies. London: Institute of Chartered Accountants in England and Wales.

McChlery, S., \& Godfrey, L. M. (2005). Barriers and Catalysts to Sound Financial Management Systems in Small Sized Enterprises. CIMA Research Executive Summaries Series, London.

Miles, R. E. (1978). Organizational Strategy, Structure and Process. New York, NY: West Publishing Company.

Moilanen, S. (2008). The role of accounting in the management control system: a case study of a family-led firm. Qualitative Research in Accounting \& Management, Vol. 5 No. 3. , pp. 165-183.

Moores, K. Y. (2001). Management Accounting systems and organizational configuration: a life cycle perspective. Accounting Organizations and Society, 26 (4), 351-389.

Nayak, A. a. (1995). The use of management accounting information for managing micro businesses. Finance and Small Firms, 182-231.

O'Regan, N., Sims, M., \& Ghobadian, A. (2005). High performance: ownership and decisionmaking in SME's. Management Decision, Volume:43 Issue:3 , Pg. 382-396.

Pansiri J. and Temtime, Z. (2006). Assessing managerial skills in SMEs for capacity building.

Perez, A. D., \& Perez de Lema, G. D. (n.d.).

Perren, L., \& Partridge, A. B. (1999). The Evolution of Management Information, Control and Decision- Making Process in Small Growth-Orientated Service Sector Businesses: Exploratory Lessons From Four cases of Success. Journal of Small Business and Enterprise Development , 5 (4), 351-361.

Quattrone, P., \& Hopper, T. (2005). 'A Time-space odyssey'. Management control systems in two multinational organizations. Accounting, Organization and Society , 30 (7/8), 735-764.

R., S. R. (1980). The real world of the small business owner. London: Croom Helm.

Randall, R. H. (1988). Can failure in SMEs be reduced by better mangementaccounting? Paper presented at 21st ISBA National Small Firms Conference: Celebrating the Small Business.

Robinson, R. (1982). The importance of 'outsiders" in small firm strategic planning. Academy of Management Journal , 25 (1), 80-93.

Ropper, S. (1997). Strategic Initiatives and Small Business Performance: An Exploratoryanalysis of Irish Companies. Entrepreneurship and Regional Development, 9, 354-64.

S.Roper. (1997). Strategic Initiatives and small business performance: an exploratory analysis of Irish Companies. Entrepreneurship and Regional Development , 9, 353-354. 
Scace R. and Goffee, R. (1980). The real world of the business owner. London: Croome Helm.

Simon, H. (1960). Administrative Behavior.

Simon, H. H. (1954). Centralization versus Decentralizationin organizing the controller's Department. New York, Ny: Controllership Foundation.

Tait, E. (1990). Owner-manager perceived management education needs: an integrative framework. International Small BusinessJournal , 8 (4), 33-48.

Thompson, A. A. (1993). Strategic management, concepts and cases,. Homewood,IL: Richard D. Irwin.

Thomson, J. L. (1999). A strategic perspective of entrepreneurship. International Journal of Entrepreneurial Behaviour and Research , 5 (6), 279-296.

Trostel, A. O., \& L.Nichols, M. (1982). Privately-held and Publicly-held companies: A comparison and management processes.of strategic choices. Academy of the Management Journal , 25 (1), 47-62.

Vaughan, L. Q.-S. (1997). 1997. Journal of the American Society for Information Science, 48 (10), 917-931.

Wyer, P., \& Mason, J. (1999). Empowerment in small businesses. Participation and Empowerment: Volume: 7/7, Pg. 180-193. 